\title{
Den uendelige bekymringshistorie: reprogenetik og reproduktionsteknologi på Christiansborg
} mange år været indlejret $\mathrm{i}$ ambivalente kulturforestillinger. I store dele af den vestlige verden har "biomanien" eller "bioforien" (Van Dijck 1998) i årtier floreret side om side med det, der kan kaldes bio-bekymringen. Og ikke sjældent er det, som da Bill Clinton og Tony Blair i skøn forening lovpriste "kortlægningen" af det menneskelige genom i sommeren 2000, bioforien, der sætter den politiske dagsorden. Vender vi blikket mod den hjemlige politiske scene, ser tingene imidlertid anderledes ud. Og det har de gjort meget længe. Siden 1984, hvor et forslag fra partiet Venstresocialisterne (VS) om midlertidigt stop for udvidet anvendelse af ny medicinsk teknologi (Folketingstidende 1983-84, 3885) affødte den første større folketingsdebat om emnet, har den danske politiske diskurs om reproduktionsteknologi og reprogenetik langt hen været én "stor bekymringsnarrativ".l

I et KKF nummer om genetiske forestil- 
linger må i det mindste en hastig gennembladring af udvalgte sider i denne tilsyneladende uendelige historie være på sin plads. Hensigten med dette indlæg er derfor kort at opsummere nogle kønspolitiske konsekvenser af denne hjemlige politiske bekymringskultur, hvis forsøg på at inddæmme og normalisere den foruroligende bio-teknologi er gået gennem en øget kontrol med det, der ofte er blevet opfattet som to sider af samme sag, nemlig det monstrøse og kvinders seksualitet. Det vil jeg gøre ved at give en meget summarisk oversigt over de to hovedetaper i de folketingsdebatter, der omhandler reproduktionsteknologi og reprogenetik (for en mere uddybende analyse, se Bryld 2001 og Lykke og Bryld 2000).

Folketingsdebatten om reproduktionsteknologi og reprogenetik kan inddeles i to faser, hvor den første spænder over tidsrummet 1984-92, mens den anden - og endnu uafsluttede - begynder i 1996. Med afsæt i VS's forslag om at standse "lægevidenskabelige forsøg med genmanipulation, kloning, befrugtning på tværs af artgrænserne og in vitro befrugtning ("reagensglasteknik")" (Folketingstidende 1983-84, 3885-86), kom 1980er diskussionen hurtigt til at fokusere på, hvordan lovgivningsmagten kunne beskytte henholdsvist fosteret og den opskræmte borger mod uansvarlige og skrupelløse læger og dermed mod de monstre, som kunne blive følgen af deres eksperimenter. De langvarige forhandlinger resulterede $\mathrm{i}$ to love, ${ }^{2}$ der begge sigtede på at lægge låg over de bekymrende udsigter. Dels underminerede begge love det lukkede ekspertvælde ved at give lægfolk udstrakt indflydelse på biomedicinsk etik, dels gav de en detaljeret liste over forbudte monsterforsøg: Kloning af mennesker, fremstilling af artmæssige hybrider (som f. eks. dyre-mennesker) mv.

Mens den politiske bekymringsnarrativ i sin optaktsfase stiler efter at fă kontrol over det monstrøse i skikkelse af uansvarlige læger og deres manipulerede fostre, går den i sin næste fase - fra omkring midten af 90erne - efter kontrollen med en anden, om end beslægtet form for monstrøsitet, nemlig kvinders seksualitet. Med vedtagelsen af en paragraf $(\$ 3)$, der som noget helt nyt direkte forbød læger at give kunstig befrugtning til kvinder, der ikke "lever sammen med en mand i et ægteskabslignende forhold", blev kvinders seksuelle orientering et omdrejningspunkt for hele den lov om kunstig befrugtning, folketinget vedtog i 1997 (Lov nr. 460). At kvinder med en 'forkert', en 'ukvindelig', seksualitet ikke skulle have adgang til IVF-behandling heller ikke hvis de selv betalte for det - bekræftedes endnu en gang, da et lovforslag om en ophævelse af forbudet blev forkastet året efter (lovforslag nr. L 53).

For flere politikere var bekymringerne over de monstrøse kvinder dog stadig ikke manet godt nok i jorden. I 2000 tog Kristelig Folkeparti og de borgerlige partier således initiativ til at forbyde også insemination af kvinder, der ikke lever sammen med en mand (ændringsforslag til lovforslag nr. L 183). Forslaget blev faktisk vedtaget, men nåede aldrig at blive realiseret, da regeringen under ledelse af Socialdemokratiet efterfølgende trak hele lovforslaget tilbage. At Kristelig Folkeparti vejrede morgenluft efter regeringsskiftet, kan derfor ikke undre. I foråret 2002 fremsatte partiet igen sit forslag om at forbyde insemination af kvinder, der ikke lever sammen med en af det rette køn, dvs. enlige og lesbiske (beslutningsforslag nr. B 81). Denne gang faldt forslaget dog (med 32 stemmer for og 91 imod), fordi den borgerlige regering dels kunne henvise til et netop igangsat udredningsarbejde og dels tydeligvist fik kolde fødder ved udsigten til den enorme "kontrolvirksomhed", forslaget ville medføre. Sundhedsminister Lars Løkke Rasmussen siger det direkte:

Hvis sanktioner skal indføres, kræver det et tilsyn og et overvågningssystem, der jo i virkeligheden kommer til at omfatte hele befolk- 
ningen. En kontrolvirksomhed af denne karakter ville altså i praksis betyde en kontrol med hele befolkningen, og det ville nærme sig noget nær en politimæssig opgave. ... En lovgivning, hvor man skal kontrollere, på hvilken måde en kvinde er blevet befrugtet, er altså at gå så tæt på privatsfæren, at regeringen i hvert fald ikke på det foreliggende grundlag vil kunne betræde denne vej. (Første behandling af B 81, min kursivering)

Selv om Løkke Rasmussen lægger afstand til forslaget, lader han alligevel en dør stå på klem. Grundlaget kan jo ændre sig. Og det gør det måske, når han senere skal præsentere folketinget for resultatet af det påbegyndte udredningsarbejde om kunstig befrugtning og adoption. For som han tilføjer, er baggrunden for dette arbejde en bevarelse og styrkelse af "grundstenen i familiens forhold". Hvilke "sten" mon han tænker på?
Noter

1. Udtrykket, den "store bekymringsnarrativ", stammer fra Dorthe Staunæs. Hun bruger det dog i en anden sammenhæng (se f.eks. Staunæs 1998). 2. Loven om oprettelse af Etisk Råd og en "regulering af visse biomedicinske forsøg" i 1987 og loven om "et videnskabsetisk komitésystem og behandling af biomedicinske forskningsprojekter" i 1992.

\section{LITTERATUR}

- Bryld, Mette (2001): "The Infertility Clinic and the Birth of the Lesbian", in The European Journal of Women's Studies 3: 299-312.

. Lykke, Nina og M. Bryld (2000): "Mellem kunstig befrugtning og naturlig intelligens. Om skiftende betydninger af køn og kvalitet", in Kvinder, Kon \& Forskning 2: 16-26.

- Staunæs, Dorthe (1998): En anden bruger? Om behandling af misbrugere med etnisk minoritetsbaggrund. Center for Rusmiddelforskning. Århus Universitet: Århus.

- Van Dijck, José (1998): Imagenation. Popular Images of Genetics. New York: New York University Press.

Mette Bryld, mag.art. lektor ved Institut for Litteratur, Kultur \& Medier, Syddansk Universitet 